Kantian Review, 26, I, I37-I62 (C) The Author(s), 2020. Published by Cambridge University Press on behalf of Kantian Review. This is an Open Access article, distributed under the terms of the Creative Commons Attributio NonCommercial-NoDerivatives licence (http://creativecommons.org/licenses/by-nc-nd/4.o/), which permits no commercial re-use, distribution, and reproduction in any medium, provided the original work is unaltered and is properly cited. The written permission of Cambridge University Press must be obtained for commercial re-use or in order to create a derivative work.

doi:IO.IOI7/SI3694I 5420000436

\title{
Responses to Critics: What Makes Mysticism Critical? (Or, What Makes Critique Mystical?)
}

\author{
STEPHEN R. PALMQUIST \\ Hong Kong Baptist University \\ stevepq@hkbu.edu.hk
}

\begin{abstract}
After summarizing the content of my book, Kant and Mysticism (Palmquist 2019), I warn against four preliminary misconceptions. The book never argues that Kant viewed himself as a mystic, fully acknowledges Kant's negative view of mysticism, offers no comprehensive overview of mystical traditions, and aims to initiate a dialogue, not to have the final word. I then respond to the foregoing essays by the five critics.
\end{abstract}

Keywords: Critical mysticism, Critique, Emanuel Swedenborg, Copernican hypothesis, conscience

\section{Introductory Disclaimers}

Kant is not generally known for his views on mysticism. This is largely because his comments on mysticism are mostly dismissive. He depicts mystics as committing one (or both) of two errors: either Wahn ('delusion' - abusing the Critical philosophy's limits on what we can know) or Schwärmerei ('delirium'I - abusing its limits on how we employ feeling). Could the writings of the Swedish mystic, Emanuel Swedenborg, have nevertheless had a formative influence on Kant's discovery of his 'Copernican hypothesis'? Kant's 1766 book, Dreams of a Spirit-Seer Elucidated by Dreams of Metaphysics (hereafter Dreams), offers a first glimpse of his ground-breaking hypothesis that the metaphysician's key task is to discern what the human mind contributes as formal (necessary and universal) conditions for the possibility of experience. As I first argued in Palmquist I988 and I989, Kant reaches this insight through a critique of Swedenborg's similar claims about the subjectively determined laws governing mystical experience of the spirit-world. 
That the first seeds of Kant's revolutionary metaphysics arose from his comparison between mysticism and metaphysics suggests that his metaphysical revolution should have a corresponding application to mysticism. Taking up this controversial suggestion, first in the aforementioned articles, then developing it further in Kant's Critical Religion (Palmquist 2000a, hereafter KCR, especially chapters 2 and IO-I2), I argued that Kant's Critical philosophy accomplishes the same two-sided goal for mysticism as for metaphysics. Just as Kant sought not to destroy all metaphysics but to distinguish false from genuine metaphysical theorizing, his Critical principles provide a way of identifying the nature of genuine mysticism, warning against the tendency to interpret mystical experience in morally injurious ways. That Kant himself never explicitly develops this secondary implication of his Critical philosophy does not make it any less relevant as part of its implications and legacy. Kant explicitly replaced traditional, speculative metaphysics with a new, Critically refined metaphysics; similarly, his system effectively replaces traditional, delirious mysticism with a new and refined Critical mysticism.

Kant and Mysticism (hereafter KM), the monograph that is the focus of this symposium, ${ }^{2}$ is a revised and extended version of the arguments regarding Kant's Critical mysticism that were spread throughout KCR. KM's subtitle, Critique as the Experience of Baring All in Reason's Light, highlights three aspects of my claims regarding Critical mysticism. First, Kant's critique of mysticism aims to shed the light of reason on an area of human experience that is all too often relegated to the dark backwaters of irrationality and the occult. Second, the focus is nevertheless on a form of experience that arises whenever we human beings encounter the boundary-conditions defining our finitude. And third, all human beings who courageously risk laying bare the core features of human experience may find themselves in the throes of such an encounter - whether or not they choose to call it mystical.

This article concludes the symposium by responding to the invaluable feedback provided in the foregoing five papers. Throughout the $K M$ project, I have been under no illusion that my controversial claims would be wholeheartedly embraced by most Kant scholars; all I may hope is that critics engage with points that are genuinely relevant to my actual argument, and I thank each contributor for valiantly attempting to do so. Indeed, the main reason for producing a more straightforward version of claims I originally advanced over thirty years ago is that those who have commented negatively about my previous work on this topic have, 
more often than not, attacked it for irrelevant or illegitimate reasons. In hopes of short-circuiting the possibility that this symposium's review essays might generate similarly misconstrued inferences about my position, I presented a brief introduction at the beginning of the original conference session (see note 2), identifying the following four claims that $K M$ is not defending.

First, KM never argues that Kant thought of himself as a mystic. Kant was a child of the Enlightenment. His acquaintance with mystical literature was limited to writers whose works he regarded as anything but enlightened. What $K M$ argues instead is that some writers of mystical literature take a broader view of what counts as mystical, and that many such mystics would recognize (indeed, some have recognized) authentically mystical themes in Kant's mature philosophical writings and tendencies in his lifestyle.

Second, KM never denies that the vast majority of Kant's own comments about mysticism are negative. Anyone familiar with Kant's corpus must admit this fact. So I am not reading Kant with interpretative blinders on, pretending he did not actually have an anti-mystical bias. However, my exegesis of Kant's texts pays careful attention to the exact wording of his negative comments, identifying precisely what it is about 'mystics' that Kant finds both unphilosophical and unworthy of emulation. Armed with this information, I show that he does not reject the whole range of what mystics sometimes include as mystical. Moreover, I highlight a few key passages where Kant reveals his fascination with the possibility that his philosophy might have mystical implications, although he himself showed little awareness of what these implications are. While fleshing out the nature and content of such mystical implications, $K M$ never claims that Kant himself already did this. Critical mysticism is $m y$ theory, not Kant's; but it (arguably) arises out of a Kantian worldview.

Third, KM offers no comprehensive overview of the mystical tradition. Although I am familiar with a range of mystical literature (having taught a course on mysticism several times and having long enjoyed reading mystical works in my spare time), $K M$ only briefly mentions examples of such literature. I limited my attention to writers whose positions have a direct relevance to Kant's philosophy, supplemented by a few samples of mystical approaches that clarify how Kant's depiction of mysticism was one-sided. As KM already exceeded the publisher's word limit by over Io per cent, I was unable to take further liberties by discussing mystical literature from other traditions. 
Finally, I never portray $K M$ as proclaiming the final word on whether or not Kant's philosophy lends itself to a mystical application or has implications that mystics can benefit from taking to heart. Rather, my hope is less pretentious, that such a short book will at least open up a dialogue so that more Kant scholars (and more mystics) will appreciate how fruitful it can be to think of Kantian philosophy (and mysticism) along the lines $K M$ sketches.

Rather than responding in turn to my five illustrious interlocutors, I devote each of the following three sections to one type of response that applies in different ways to each review essay. Section 2 corrects factual errors or clarifies misconceptions expressed by the five critics. Having further clarified what is not intended by ascribing a form of mysticism to Kant's philosophy, I respond in section 3 to various points of substantive debate raised by the critics, focusing mainly on the legitimacy of KM's underlying hermeneutic strategy. I then conclude in section 4 by taking a step back and challenging the community of Kant scholars to consider what better way we have for making Kant relevant in today's ever-changing world, if not by taking Critique to be, at its deepest level, a morally empowering experience that is not reducible to any other and which therefore shares features with types of experience that many have called mystical.

\section{Clarifying Misconceptions: Must Mysticism be Delirious?}

Maharaj lists four key claims defended in $K M$ and finds two 'fairly convincing' (p. I06). I focus here on the first claim he disputes. (On the second, concerning my interpretation of conscience, see section 4.) He reads $K M$ as attempting to prove (ibid.) that 'Kant himself was a mystic or at least had strong mystical tendencies'. This phrasing, while not technically wrong, could be misleading if taken to imply that $K M$ portrays Kant as viewing himself as a mystic. KM makes no such claim. Moreover, many self-described mystics would resist counting Kant as mystical, for Kant never claims to have had special encounters with the transcendent, which many mystics (e.g. Swedenborg) identify as the sine qua non of mysticism. None of this conflicts with KM's actual, more modest claim: some mystics have defined mysticism in ways that would (or at least, could) include Kant, given certain well-documented tendencies he exhibited in his personal life and writings. Echoing a theme of KM, Maharaj cites Vaihinger, one of the earliest scholars who highlighted Swedenborg's influence on Kant. What Maharaj leaves unsaid is that KM cites not just Vaihinger, the non-mystical interpreter of Kant, but also Carl du Prel (I839-99), the older and avowedly mystical 
interpreter, whose scholarly attention to the Swedenborg-Kant relationship influenced Vaihinger. Maharaj's silence regarding du Prel is significant because du Prel illustrates how mystics sometimes count Kant as a fellow traveller along the mystical path.

The actual argument Maharaj presents against my claim that Kant can be viewed as someone whose life and teachings exhibited mystical tendencies rests on a misunderstanding, not a substantive disagreement. Maharaj finds 'no justification for taking' (p. I08) Kant's various claims about 'reverence for the moral law ... to be mystical'. Here Maharaj ignores the evidence $K M$ provides - evidence McQuillan acknowledges (p. II7) - grounded in the claims some mystics (e.g. Albert Schweitzer) have made about the necessarily moral orientation of authentic mysticism. Maharaj questions KM's claim that Kant also exhibited a 'meditative attitude toward nature' (p. I08), suggesting that, even if this is true, 'there is still a world of difference between a meditative attitude and a properly mystical bent of mind'. But this depends on how one defines mysticism - a question I tackle in section 4 . For now, suffice it to say that $K M$ never asks that interpreters 'necessarily' (ibid.) regard Kant as a mystic, but argues only that plausible evidence supports those who prefer reading Kant this way. As we shall see, the plausibility of KM's interpretation of Kant's life and teachings turns on whether one accepts my basic claim that mysticism, properly understood, encompasses the mental attitude that Kant calls 'Critique'; those who maintain the common assumption that authentic mysticism requires a delirious component will find my evidence unconvincing. ${ }^{3}$ As such, the onus of proof is on Maharaj to define more explicitly his view of mysticism 'proper'.

Two relatively minor clarifications supplement the foregoing. First, Maharaj thinks my new translation of Schwärmerei is 'misleading' (n. 4) because " "delirium" has the connotation of false knowledge, not implied by "Schwärmerei". I agree with his latter claim but dispute the former. As explained above (section I; cf. KM, p. 65), Kant identifies the two main religious errors as Schwärmerei (delirium) and Wahn (delusion), where the latter alone entails false knowledge; the former entails false feeling, bordering on mental illness (p. 75 , n. 4 ; cf. Religion, 6: I63-75). As I argue elsewhere (see note I), 'delirium' aptly expresses these and other key features of Kant's understanding of Schwärmerei, while avoiding the misleading connotations - which Maharaj concedes - of 'fanaticism' and 'enthusiasm'. Those who remain unconvinced should explain why the considerable advantages I ascribe to 'delirium' 
do not apply, then recommend a new translation that is better than all three existing options.

The second minor clarification concerns Maharaj's own past work on Kant's view of mysticism. Maharaj (20I7) brilliantly analyses precisely how Kant's philosophy allows and forbids various types of mystical experience. Fortunately, his article appeared just in time for me to incorporate some of his key insights into KM's final manuscript. As such, Maharaj accurately reports that $K M$ 'summarizes and endorses my position' (n. 5). Of course, $K M$ thoroughly reworks arguments I first advanced in the 1980 s (see note I), then later incorporated into KCR, which Maharaj (2OI7) cites in the process of championing some of KCR's basic claims. That he agrees with some of KM's paramount claims, therefore, is not surprising. He exercises admirable self-restraint in not using his symposium article to promote his own taxonomy of technical terms for interpreting the sometimes perplexing implications of Kant's epistemology for mysticism; to reward his humility, my first response to the doubts intoned by several of the other critics on this very point is to recommend they read Maharaj (2017).

In contrast to Maharaj, Firestone alleges that I merely 'redefine [Kant's] terms and thereby easily dismiss Kant's consistent marginalization of mysticism' (p. I02). Yet KM is far from merely dismissing Kant's explicit and repeated rejection of mysticism; rather, I face this (undisputed!) fact squarely and respond explicitly. I argue that Kant was not well informed of the range of views that might count as mystical, having drawn his understanding of 'mysticism' primarily from reading Swedenborg. Kant wrote as if all mystics commit the errors of Swedenborg, Kant's model of a religious 'deliriac' (Schwärmer). Ending KM with a Wittgenstein quote illustrates that there is more than one way to embrace mysticism without condoning delirium. Yet Kant's Critical mysticism is not exactly 'a forerunner of the early Wittgenstein' (ibid.). Unlike Wittgenstein (who endorses total silence when encountering the mystical), Kant bids us to critique all aspects of human experience - including the unknowable reflecting on the implications of whatever mysteries we encounter (e.g. Religion, 6: $137-47$ ) for the meaning of human life.

Without mentioning Wittgenstein, Nelson similarly portrays Kant's philosophy as incompatible with mysticism on the grounds that it breaches the transcendental separation between ... the sensible and its conditions and the supersensible whereof nothing cognitively meaningful can be stated' (p. I23). Wittgensteinian silence is one expression 
of Kant's principle that we cannot say anything 'cognitively meaningful' about the supersensible. But here Kant would emphasize theoretical cognition; otherwise, he would break his own rules whenever he appeals to noumenal causality, the universal voice of the moral law, etc. Unlike Wittgenstein, Kant's antidote to the error of 'improper dabbling in the transcendent' (p. I23) is not to order: No dabbling allowed! Instead, he advises: Recognize your theoretical ignorance of any cognitive assertion about the transcendent, then humbly accept that our moral nature impels us to stake a faith-based claim on the transcendent! This twofold response conveys the fundamental grounding of both Critical metaphysics and Critical mysticism.

Firestone's portrayal of $K M$ as arguing that 'Kant's philosophy is religiously mystical or ... culminat[es] in a transcendental type of religious mysticism' (p. Ioo) could mislead anyone who assumes 'religious mysticism' must be delirious. A clearer way to express my position would be: Kant's Critical philosophy, as such, is non-religiously mystical i.e. mystical without requiring commitment to any given religious tradition. Moreover, the Critical system does not merely culminate in mysticism; concepts amenable to refined forms of mysticism permeate all three Critiques, from the basic appearance/thing-in-itself distinction, through the cognitive priority of transcendental apperception, the ultimate unknowability of reason's three ideas, and the immediate (yet theoretically unprovable) awareness human beings have of their freedom and of 'the moral law within', right up to the third Critique's four paradoxical 'moments' of beauty, its affirmation of the sublime as an experience of the incomprehensible, and its portrayal of genius as grounded in 'spirit'. None of these (and other) key concepts of Critical philosophy are explicitly religious; yet they all have mystical connotations. Firestone's statement accurately summarizes KCR's position regarding the Critical philosophy's overall religiously affirmative orientation. A key reason for extracting that book's arguments about the mystical subtext of Kant's thought and consolidating them in KM was to show how Critical philosophy leads to an affirmation of religion: the three Critiques themselves are (with a few rare exceptions) not explicitly religious; they are nonreligiously mystical. This is precisely the feature of Kant's system that orientates it towards a (potential) affirmation of religion.

Firestone goes on to assess two of KM's alleged claims - 'mystical experience promotes moral decision-making' and 'immediate mystical encounters serve to unify or make whole human experience' (p. I02) as 'groundless' and 'dangerous to reason', such that they must 'remain 
outside the Critical philosophy altogether'. However, KM does not say all mystical experiences have these characteristics; rather, I claim that Kant's critique of mysticism does not disallow all mystical experience, but only those forms that fail these two Critical tests. KM argues that Kant's philosophy (not all mystical experiences generally) aims to promote human moral development by providing an 'idea of the whole' (of human experience, through the ideas of reason), ${ }^{4}$ and that insofar as mystical experiences achieve this goal (as some but not all mystics claim they should), the two are compatible. I claim not that Kant himself regarded his Critical system as mystical but that mystics have (in fact) and can (without distorting facts) draw relevant insights from his mature philosophy.

Nelson challenges my reading of Dreams, suggesting I took its references to Swedenborg as being more central to Kant's purpose for writing that book than they really were: if 'the problem of metaphysics' was Kant's main focus in Dreams, not 'the problem of mysticism' (p. I2I), then Swedenborg serves merely 'as a parody and illustration of the absurdity of [especially Leibnizian] speculative reason and experience'. What merits clarification here is that $K M$ never denies the legitimacy of this standard reading. Kant wrote Dreams as a philosopher, not as a mystic; when he acknowledges the surprising overlap between Swedenborg's metaphysical explanations of how mystical visions occur and the metaphysical theories Kant himself had previously defended, the likely unstated subtext is that this similarity arose from their common dependence on Leibnizian/Wolffian metaphysics. Nothing in KM precludes viewing metaphysics as Kant's main (bidden) concern in Dreams.

$K M$ argues that this standard reading by itself does not tell the whole story of Dreams. First, the book's title explicitly makes mysticism the main topic and metaphysics the 'illustration' - not vice versa. ${ }^{5}$ Perhaps this was merely a rhetorical ploy. Yet the fact remains that Kant used this ploy: his book claims to be primarily about 'spirit-seeing'. Second, Dreams explicitly posits a metaphorical relationship between mystical visions (sensation-dreaming) and metaphysical speculation (reasondreaming). Third, given this metaphor, the fact that Kant revolutionizes philosophy during the following twenty-five years, not by denying the possibility of all metaphysics but by proposing a new and proper form of Critical metaphysics, implies that the same can be done for mysticism. The traditional reading ignores (or, at best, downplays) this possibility, whereas $K M$ explores just how this much-neglected implication can be developed. That is, while granting Nelson's insistence that Kant's 'central 
concern' in Dreams was (implicitly) 'with philosophical metaphysicians' (p. I2I), KM emphasizes what most interpreters suppress: Kant's argument, taken at face value, also underscores the need to reconceive mysticism. He eventually came to call his philosophical method 'Critique', though without explicitly acknowledging that his critique of metaphysics has a mystical flip side, and that the seeds of both first sprouted in his response to Swedenborg.

The immediately preceding sentence encapsulates my reply to McQuillan's criticism of the argument in KM's part I. McQuillan's worries arise from his conflation of two terms I carefully distinguish, though many Kant scholars treat them as synonyms: 'Critical method' and 'Copernican hypothesis'. ${ }^{6} \mathrm{KM}$ follows my early publications on Kant by using the expression 'Critical method' to refer to a perspectival way of arguing that operates throughout Kant's published (and in many unpublished) writings: he tackles philosophical problems by looking first at one extreme solution, then examining a solution that stands diametrically opposed to the first; finally, he affirms a third option that synthesizes the first two, enabling us to see how both standard answers are partly true and partly false. By contrast, 'Copernican hypothesis' refers to Kant's new strategy for solving the key problems of metaphysics, which he first employs partially in the 1770 Inaugural Dissertation, then fully develops in his I78I Critique, but never actually names until the second edition Preface ( 1787 ). Regarding the former term, KM straightforwardly demonstrates that part one of Dreams exhibits just such a triadic/Critical argument. Regarding the latter, however, KM argues that the so-called Copernican hypothesis - i.e. the assertion that what is necessary about human knowledge is rooted in the knowing subject, not in known objects, as justified by the Critique's proofs that space, time and the categories are synthetic a priori conditions for the possibility of human cognition - never appears in the text of Dreams, nor did Hume ever advance any such arguments, but that such a hypothesis can be detected in Swedenborg's writings, as he conjectures how the spirit world differs from the world of ordinary human experience.

McQuillan's objections to the arguments of KM's part I totally neglect this crucial distinction. He correctly says 'that Palmquist thinks Kant had already formulated his critical method in the mid-I76os'- indeed, much earlier than that! Hence, I never claim this method 'emerged from [Kant's] reflections on Swedenborg's mystical visions' (p. I I4). When McQuillan grants that $K M$ offers 'many suggestive quotations ... about Swedenborg's influence on ... the development of Kant's 
critical method' (p. II4), he therefore should have written 'of Kant's "Copernican hypothesis". Otherwise, I could not have portrayed Dreams as providing 'a test case for the application of [Kant's] well-formed Critical method' (KM I9) - a passage McQuillan quotes twice (pp. II3, II5) but reads as if I had written 'well-formed Copernican hypothesis'. McQuillan would be right to find this claim incredible, had I really used the latter term, since (as he skilfully demonstrates, and as I fully agree) the latter was far from being 'well formed' in the 1760 s. $^{7}$ When McQuillan repeats his worry about this point, he goes too far by claiming that (what I would call the new application of) the Critical method that Kant employs in the first Critique (i.e. the Copernican hypothesis) does not appear 'at any point in [Dreams]' (p. I I 6) $;{ }^{8}$ for Kant does allude to the Copernican hypothesis in the final chapter, stating for the first time that, to solve the problems laid out in Dreams, 'science' must discover 'the bounds imposed on it by the nature of human reason'. 9 As countless past interpreters have noted, this statement prefigures Kant's mature recognition of the Copernican (i.e. self-Critical) path reason must tread to solve the metaphysical problems raised by Swedenborg's failed attempt to explain mystical visions.

McQuillan's observations regarding Kant's interactions with Mendelssohn in the I 760 s lead him to propose 'alternate readings' of several passages I quote from Kant. Despite his suggestions to the contrary, McQuillan's explanations of these passages are fully compatible with my own, once the Critical/Copernican distinction is properly understood. Kant surely was sympathetic with Mendelssohn's misgivings about Swedenborg (see note II); and, throughout the I760s, Kant himself (like Lambert) did struggle to develop a fresh strategy for solving metaphysical problems, so that 'Kant was in no position to publish anything "wellformed" when he published [Dreams]' (p. I I 5). Yet these affirmations in no way compromise my two main claims in part I, that (a) Dreams exhibits the standard perspectival (threefold) methodology that characterizes Kant's Critical method, ${ }^{10}$ and (b) Swedenborg's (perhaps Leibniz-inspired) interpretations of his own visions - though not the visions themselves - are the best historical evidence we possess of writings that could have prompted Kant to discover the strategy that later came to be known as the Copernican hypothesis. In short, Kant learned nothing from Swedenborg about philosophical methodology; his new (Swedenborgian) insight was that the forms of human cognition reside in the subject, not in the known object. ${ }^{I I}$ 
Pasternack correctly understands my distinction between the Critical method and the Copernican hypothesis, but alleges that my perspectival interpretation of the latter depicts it as 'something like an interpretative stance' that human beings are capable of 'setting ... aside' (p. I3I). I fully agree with Pasternack that Kant's Copernican hypothesis is 'a description of the relationship between our faculties and the world' (ibid.); but it is a transcendental description, not an empirical one. It provides a mechanism for solving otherwise intractable philosophical problems by grounding them in human finitude. Although the formal conditions imposed on our experience are absolute, ${ }^{\mathrm{I} 2}$ this does not require everyone always to speak and act in Copernican terms. (We can talk accurately about the sun 'rising' while acknowledging that, astronomically, it does not actually rise.) Ignoring Kant's perspectivism, Pasternack doubles down: 'I do not see room in Kant for human consciousness to have "encounters" if by that Palmquist means a contentful sensible awareness that is not determined by the operations of our faculties' (ibid.). This depends on what 'contentful' means. KM actually denies that we can have awareness without the operation of any human faculty; that would require intellectual intuition. Rather, Critical mysticism is grounded on the possibility of mono-faculty experiences. Just as great mystics down through the ages have emptied their faculty of understanding through contentless (but thought $f u l$ ) meditation or blinded their faculty of sensibility through content $f u l$ (but thoughtless) contemplation, so at $\mathrm{A}_{5} \mathrm{I} / \mathrm{B}_{75}$ Kant famously contrasts unconceptualized spatiotemporal intuitions ('blind' encounters) with contentless thought ('empty' encounters). Kant's explicit acknowledgement that such encounters occur comes with an oft-repeated warning: they might feel good, but they cannot ground scientific knowledge claims. Perhaps this is why Kant forbade discussion of Critical philosophy during his dinner parties: although the Copernican hypothesis, as Pasternack rightly observes, assigns 'an ineluctable role for the categories' (ibid.), friendly conversation obliges us to bracket such transcendental assumptions when the situation calls for the immediacy of personal encounter. ${ }^{\mathrm{I}}{ }^{3}$

\section{The Hermeneutic Challenge:}

\section{Interpretation as Exegesis - and Beyond}

Maharaj identifies a 'fundamental hermeneutic problem that casts a shadow over $K M$ as a whole' (p. I Io): '[Palmquist] does not sufficiently reflect on, or justify, his unusual interpretative procedure of reading Kant against Kant by claiming, against Kant's explicit intentions, that certain experiences central to Kant's philosophy are, in fact, mystical.' Ironically, he then accurately states my rationale for this procedure, that Kant 'had 
an unduly narrow understanding of mysticism' (p. I06). Maharaj challenges my understanding of what 'mysticism' can possibly mean - an objection I shall tackle in section 4. By contrast, Firestone apparently writes with approval when he acknowledges (p. IOI) my skill 'at teasing out these suggestive tropes and trajectories in Kant's thinking and leveraging them for [my] interpretative ends'.

As it turns out, Firestone's apparent praise of my hermeneutic 'leveraging' is also a set-up for his primary criticism: I allegedly display 'a penchant for making "inferences of possibility" into "inferences of actuality" (ibid.). To illustrate this tendency, Firestone highlights my appeal to 'immediate experience' - a strategy that dates back to my earliest publications, ${ }^{14}$ where it served interpretative purposes unrelated to mysticism or religion. My contention that Kant's theoretical philosophy implicitly relies on a conception of immediate experience - even though (as Firestone rightly notes) Kant himself uses 'experience' (Erfahrung) almost exclusively to refer to mediate experience (a synonym of empirical cognition) - arose solely from my attempt to understand his epistemology.

Pasternack astutely observes (p. I30) that Kant himself occasionally uses 'immediate experience' - twice in the Refutation of Idealism (B275-6) and elsewhere. Indeed, my original goal was to raise Kant's occasional usage to the status of a technical term. ${ }^{\mathrm{I} 5}$ Although Firestone may well be statistically correct to claim that most Kant scholars 'would think that, to have any experience at all is, in the Critical writings, to have what one might call a "mediated experience", (p. IоI), this does not preclude the legitimacy of making finer distinctions based on Kant's hints. Indeed, many interpreters of Kant similarly appeal to implicit claims that must be affirmed in order to account for stated claims in Kant's epistemology. For example, by coining the term 'rogue objects', Hanna (e.g. 20I I) likewise fills a real interpretative need, giving interpreters a concept for something Kant talks about but never explicitly defines. Hanna's (Kantian) 'rogue objects' are part of the same feature of human (pre)cognition as my (Kantian) 'immediate experience'. The fact that Kant himself never (in Hanna's case) or only rarely (in my case) uses the newly introduced technical term does not invalidate its hermeneutic legitimacy. Rather, I see a key interpretative task as looking for precisely such lacunae in a text and filling them with insightful new ways of explaining what the original author left unexplained. I thus plead guilty as charged to Firestone's allegation that I do this; yet, far from invalidating my interpretation, nothing 'fishy' swims in this hermeneutic 'BARL' (ibid.). 
Prior to the publication of Gadamer's ground-breaking work, Truth and Method, one could be forgiven for alleging that reading something into a text invalidates one's interpretation. But in the wake of other, more radical hermeneutic theories advanced by various philosophers since then (such that, in some cases, 'anything goes' provided one has fun playing with the text), my hermeneutic philosophy should not seem radical: responsible hermeneutics always requires a combination of 'exegesis' (reading objective meaning out of the text) with its opposite, 'eisegesis' (reading subjective meaning into the text). When teaching hermeneutics, I show how Kant himself was one of the first major philosophers to defend a hermeneutic theory that encourages interpreters to prefer meaningful interpretations that may be loose to objectively accurate interpretations that lack meaningful insight. Kant himself defends this position in Religion, devoting an entire section (6: I09-I4) to examining the proper way of interpreting the Bible in a church: anyone concerned with promoting authentic religion should opt for a moral interpretation, even if the author's original intent was not to convey a moral meaning. Similarly, when I introduce a new technical term while interpreting Kant, I am not, as Firestone alleges, presenting my 'hypothesis as Kant's, both in terms of content and modus operandi' (p. IO2). Rather, I welcome readers to view my application of such innovations as reconstructions rather than straightforward exegesis. ${ }^{16}$

The same would be true for the plausible hypothesis Firestone proposes, regarding a possible hermeneutic key to interpreting Kant's Opus Postumum, that Kant was there responding to the newly emerging German idealism (p. I04). Nelson treats just such a reading of Opus Postumum as self-evident (pp. I24-5). Likewise, I see no necessary incompatibility between my interpretative hypothesis - that Opus Postumum offers a final, all-encompassing statement of Critical mysticism - and Firestone's. What baffles me is his undefended conclusion that my hypothesis is 'a hermeneutic impossible possibility', just because '[t]oo many "good" hypotheses exist' (pp. I03-4). Surely two (or more) plausible and non-contradictory hypotheses can be simultaneously true!

If one must choose just one interpretation of Opus Postumum, the one defended in KM's part III has a distinct advantage over the one Firestone advances hypothetically and Nelson takes as obvious. The chief drawback of their (conventional) reading is that it assumes the Opus Postumum is a series of 'departures from the spirit of the Critical philosophy' (Nelson, p. I25). On my reading, by contrast, these unusual features are not a departure from, so much as the culminating application of 
Kant's Critical principles. They appear to be a departure only when we fail to recognize that, with the synthetic (transcendental) and analytic wings of his system (more or less) complete, Kant's remaining task was to complete (in the Opus Postumum) the metaphysical wing with a final book synthesizing the metaphysics of nature and the metaphysics of morals in a (Critically) mystical account of the metaphysics of the whole (see Palmquist I993: 9I-I03).

Although KM's use of 'immediate experience' is grounded in Kant's usage, its application is primarily my invention. This is unambiguously true for the term 'encounter', newly introduced in KM to accentuate certain mystical implications of Kant's essentially epistemological term, 'immediate experience'. Firestone could not be more wrong, however, to assume either of these overlapping terms 'must mean an unconditioned experience' (p. I02). Given that he assumes this incorrect premise, his conclusion surely follows: 'I do not think this is in Kant's mind at all' (ibid.). An unconditioned experience would require intellectual intuition, which Kant consistently repudiates. (Kant's rejection of intellectual intuition is precisely what makes him a Critical mystic, rather than an ordinary - e.g. Swedenborgian - one!) I do not know why Firestone thinks my appeal to 'immediate experience' refers to unconditioned experience; this would obviously be 'an oxymoron for humans', precisely because '[w]e are defined by our limitations' (ibid.). Again, 'immediate experience' actually refers to intuitions that we receive (either through outer or inner sense, or both) which cannot (or have not) rise(n) to the level of empirical cognition by being conceptualized. By contrast, 'mediate experience' refers to our normal, conceptualized awareness of intuitions. Immediate experience, then, is intuitive experience as such, sans conceptualization.

Kant acknowledges two types of theoretical limiting conditions: space and time determine how any intuition must appear to us; the categories determine how any conception must be thought by us. Immediate experience, for us humans, is conditioned in the former sense, not the latter. The feeling of having had wholly unconditioned experience would constitute what Kant labels 'delirium'; his rejection of it is precisely what makes Kantian mysticism specifically Critical. Thus Firestone's claim that 'God alone experiences the world in an unmediated way' (ibid.) is either true or false, depending on which type of experience is intended. If 'experiences' refers to knowledge-generating cognitions, then Kant's position is that God alone has such unconditioned experience; but if 'experiences' refers to the immediacy of intuition, then we share with 
God an ability to experience the world immediately. The crucial difference is that God (through intellectual intuition) gets knowledge immediately, whereas our merely sensible intuition (being 'blind') gets us no theoretical knowledge unless it is mediated by conception. Subjecting our immediate experience to critique puts us on the path that every good mystic shares with every good philosopher, the path to wisdom.

Kantian wisdom acknowledges significant differences between theoretical and practical reason. As Pasternack notes, 'the truths of practical reason are isomorphic between human beings and God', for 'practical reason puts us in touch with morality itself' (n. 4). Yet even here, wisdom requires us to acknowledge human limits: God's moral judgement is noumenal; ours is phenomenal. As we always judge in the presence of obstacles (i.e. inclinations), our good moral choices are virtuous at best, whereas divine moral judgement is holy (cf. Religion, 6: 46-7, I37-9). Nevertheless, the ideal Pasternack highlights remains within our reach: Kant argues that, through a (timeless) conversion - a deeply personal experience, reorienting one's conscience - the human heart can be judged as holy, recovering practical reason's purity. The divine-human moral unity that Pasternack highlights is realizable only through a (Critically mystical) experience of the noumenal mystery that is morality's source in practical reason.

Nelson broadens the hermeneutic aspect of this discussion to include Eastern as well as Western philosophical (and mystical) approaches. This is helpful because Eastern philosophy tends to preserve the classical notion of philosophy as a path to wisdom better than Western approaches typically do. Thus Nelson's discussions of the nest of interpretative difficulties surrounding Kant's view of Spinoza (and/or Malebranche) and of Kant's tendency to dismiss Chinese philosophy as 'pantheistic mysticism and Spinozism' (p. I22) are instructive. Nelson is undoubtedly correct that these (different but parallel) issues illustrate how deeply concerned Kant was to avoid expressing sympathy with anything that smacked of pantheism or mysticism. But as he indicates, Kant's stance here 'is interconnected with his ethical reinterpretation of the religious' (ibid., my emphasis). Likewise, by questioning the accuracy of Kant's interpretation of Asian philosophy (pp. I 22-4) - a concern I share (see e.g. Palmquist 20I3) - Nelson implicitly affirms my view that we need not accept something as true merely because Kant said so. Just as Kant had only a limited exposure to Asian philosophical traditions, his exposure to mystical literature was limited, such that we should have no qualms about challenging his limited account of both. 
In short, Kant himself employed an intentionally hermeneutic strategy, and so do I. Yet KM never identifies my hermeneutic strategy with Kant's; far from it. The book explores how far Kant's philosophy can be read as illustrating an expanded account of what the word 'mysticism' can (and, arguably, should) mean. My argument would be far-fetched, were it not for the fact that many mystics around the world have actually adopted such an expanded hermeneutic of mysticism. My hope is that Kant scholars will not close their minds to a new mode of interpretation, simply because it is new, or simply because it is a mode of interpretation, not merely a historical-literal reading of the text.

\section{Conclusion: What Makes Critique Mystical, and Why Should we Care?}

Kantian Critique, above all else, is a distinctively human way of being-inthe-world, one that in my view, as Nelson correctly states (pp. I20-I), requires us always to think perspectivally - i.e. to consider both (or all) sides of any philosophical debate, seeking to identify the perspective from which each side expresses an element of truth, before moving beyond such (typically) binary choices to discover a more expansive vision of the way things are. Kant applies this threefold Critical method of thinking - identify a position, contrast it with its opposite, then find a higher position that synthesizes the opposites - throughout his writings. Nelson's essay aptly underscores how this perspectival interpretation of Kant is necessarily holistic and that seeking a holistic vision of our beingin-the-world is a central feature of Kant's Critical mysticism. Kant does not merely reject the possibility of intellectual intuition (i.e. of traditional delusory metaphysics and delirious mysticism); he also replaces it with an 'idea of the whole' that must be grasped if we are to see the world (and Kant's philosophy) aright. As Nelson insightfully observes, such holistic vision is central to many Eastern forms of (mystical) thought - and to some forms of Western mysticism as well, I would add. Thus, recognizing that Kant dismissed Eastern philosophies and religions only because he thought they were mystical in the wrong way leaves more room than has typically been acknowledged for sketching parallels between Kantian and Eastern traditions. ${ }^{17}$ Although he meant it as a term of disparagement, I argue (Palmquist 1996) that Nietzsche's description of Kant as 'the Chinaman of Königsberg' conveys a truth whose depth has yet to be fully plumbed.

In response to KM's argument about Kant's apparently supportive reference, in an appendix to The Conflict of the Faculties, to C. A. Wilmans' account of a group of mystics who appeal to conscience as an aspect of 
their mystical experience, Maharaj accuses me of 'mak[ing] the mistake of generalizing from the experience of a small group'; he claims 'Kant himself considers ... [their experience] to be an anomaly' (p. I09). Wilmans' description of that separatist group is indeed anomalous, for very few religious groups interpret their beliefs and practices in Kantian terms. Likewise, Kant himself probably regarded their interpretation as anomalous - otherwise, why devote an entire appendix to it? - though he never explicitly states this. Moreover, an example being unusual does not negate the possibility that it may correct the norm. Indeed, Kant's general view of the role of examples in moral and religious instruction is precisely this: they serve as anomalies that can motivate the weak-hearted to believe we can do it too! KM would have committed the error Maharaj attributes to it only if I had argued that everyone is as that group of separatists was; but I never made this claim. Rather, this group of religious separatists properly exemplified the attitude towards conscience that Kant also defended - and they called it mystical. ${ }^{18}$ Maharaj himself commits the mistake of generalizing from the particular, if he somehow thinks that, by citing this example, Kant meant to show why the separatists' interpretation of conscience as a mystical experience could not be true. Such a usage would be glaringly inconsistent with Kant's use of examples elsewhere.

Although he does not mention Wilmans, Pasternack's reflections on 'supervening mysticism' may be instructive here. Pasternack treats the example of a religious person experiencing God through 'the sound of church bells' as a 'second way' of 'present[ing] mystical experience' ( $p$. I3I). Given that he mistakenly thought my standard account of mystical experience entails a total abandonment of the (Copernican) conditions for the possibility of experience - a misunderstanding I have clarified above (section 2) - it is not surprising that Pasternack sees this as a distinct type, rather than an aspect of all mystical experience. All mystical experiences start with some element of ordinary experience (either bare intuition without conceptual clothing or bare thought without intuitive embodiment), then typically proceed to some interpretation of one's immediate experience. Once a person conceptualizes the bells-ringingintuition by thinking 'God's presence' rather than 'bells ringing', the immediate experience has indeed, as Pasternack says, become mediate. In this case, the ringing bells serve as what Kant calls a symbol of the transcendent reality that the believer takes to be supervening upon them. Discussing Kant's theory of symbolism here would require an unnecessary digression. Instead, suffice it to say that, although most religious people do interpret their experiences symbolically, as if something 
transcendent - i.e. something conceptualized as the unity or totality of all being - were supervening on otherwise ordinary phenomena, the most advanced forms of mysticism do not require such interpretation. This is not a matter of two types of mysticism but two ways of responding to one and the same thing, immediate experience. Critical mysticism requires a person either to forego any presumptuous interpretations, perhaps like Wilmans' separatists, or to limit one's interpretations to symbolic statements, avoiding literal knowledge claims. ${ }^{19}$

The last published work that Kant penned with his own hand was a Preface to a book written by his friend, Reinhold Jachmann - a sustained refutation of the claim, defended in Wilmans' doctoral dissertation, that Kant's philosophy implicitly affirms a special kind of mysticism. Jachmann, a pastor, asked Kant to write the Preface probably in hopes that the master would endorse his own view that Kantian religion is inconsistent with mysticism. Yet Kant, convinced that a truly Critical thinker must be open to seeing both sides of a dispute as (at least partially) legitimate, likely disappointed Jachmann. Without explicitly taking sides, Kant does exactly what he would be expected to do, if KM's claims hold: emphasizing the goal of seeking wisdom through enlightened Critique, he identifies the self-contradiction inherent in delirious mysticism, but leaves readers to decide for themselves precisely how Critique provides an antidote. Had Kant considered employing the key term I have introduced, 'Critical mysticism', he could have expressed the same thoughts conveyed in his Preface by saying: Critical philosophy rejects the standard mysticism that infuses wisdom only 'from above' (as literal revelation), but could support the more moderate path of mystics such as Wilmans, who allow practical reason to scale wisdom 'from below' (8: 44I), as symbolic revelation.

Maharaj further objects (p. Io9) that 'our direct awareness of the categorical imperative is not a mystical experience of God but a faithbased interpretation of the categorical imperative as originating in God'. While Kant certainly would affirm the latter, Maharaj offers no argument supporting his assumption that Kant could not also affirm the former, provided the mystical experience does not contravene his Critical principles by being delirious. ${ }^{20}$ If readers consider the strength of Kant's arguments and decide on that basis to postulate (with Kant) the categorical imperative's divine origin, this alone would indeed be merely a statement of rational faith. ${ }^{21}$ But if, while engaging with Kant's Critical project, his reader experiences a 'direct awareness' of the moral law, why not call this a mystical experience? Kantian 'rational 
faith' is ultimately more than just a process of logical reasoning. Given Kant's appeal to the noumenal as the ultimate source of human freedom, he should readily affirm that those who gain such newfound moral awareness are directly encountering what some theologians call 'ultimate reality' - though without justifying a knowledge claim that we are free or that God exists, for such inferences would indicate that one has fallen into the twin errors of delusion and/or delirium.

A criticism common to Pasternack, Nelson and Maharaj is that KM adopts an incorrect notion of what 'mysticism' actually means. If, following Maharaj, we limit the term to its etymology, such that it refers only to experiences that are 'both private and rare and hence cannot be the common property of all' (p. I Io), then KM's argument would ultimately fail. However, as explained in section 3, my hermeneutic strategy takes the (good) interpreter's task to include questioning such established assumptions. As such, my neologism ('Critical mysticism') is intentionally paradoxical - along the same lines as many of Kant's own technical terms, especially in the third Critique, such as 'subjective universality' or 'necessary delight'. ${ }^{22}$

Maharaj's claim that 'the experience of conscience cannot be mystical, precisely because it must be a universally shared experience grounded in practical reason' (p. I Io), reveals that we disagree not on the substance but on proper terminology - and perhaps also on what range of claims mystics down through history have actually affirmed. 'Calling the experience of conscience "mystical"' would amount 'to depriving the experience of its universality' (ibid.) only if 'mystical' necessarily entailed 'delirious'. Yet KM rejects that entailment from the start. Again, if Maharaj refuses to accept my revision of the relevant terminology and persists in thinking 'full-blooded' mysticism must be private (ibid.), then of course he will be unlikely to appreciate any potential profundity in my conclusion. By contrast, when Nelson compares KM's portrayal of Critical mysticism with Mou Zongsan's assessment of Kant's theory of intellectual intuition, he ends up supporting my core argument regarding conscience: I agree that, if Mou's theory of intellectual intuition is to be acceptable, it must not refer to private mystical experience in the traditional, delirious sense, nor can it be limited to the Chinese people (as Mou sometimes claims); 'rather, it belongs to everyone' insofar as it refers to holistic experiences that are 'disclosed not in the fantastic but in ordinary encounters' of various types (pp. I $25-6) .{ }^{23}$ 
A main claim of $K M$ is precisely this: although many adepts delude themselves into believing their experiences are special or unique, viewed rightly, mystical experiences tap into something universal in human nature. This is the core insight of Kantian Critical mysticism, an insight that strikes me as profound, even though dyed-in-the-wool deliriacs might regard it as merely 'water[ing] down the concept of mysticism to the point where it becomes virtually meaningless' (p. I Io). Contrary to Maharaj's concluding claim, however, $K M$ performs this diluting function not by 'conflating mystical experience with the aesthetic experience of natural beauty and the experience of conscience', but by reinterpreting such experiences, just as some past mystics have done.

Pasternack likewise questions whether 'mystical' is the correct word to describe the sorts of experiences Kantian Critique explains and/or encourages. In line with KM's overall argument, he thinks it is 'a tenable view consistent with Kant' that a person may 'find greater strength in their ongoing moral efforts' by 'periodically reflect[ing] back upon a religious or mystical experience', but adds that 'it is hard to regard [this] as mystical in the typical sense of the term' (p. I33). Likewise, Pasternack finds it 'incorrect to regard our consciousness of the judgements of conscience as' having mystical implications (ibid.). Here, however, I dispute his association of conscience with reason's 'practical applications': Pasternack mentions only Kant's theoretical and practical standpoints and neglects the all-important third Critique. Yet Kant's theory of conscience aligns with the judicial standpoint, not the practical. Once we give the judicial standpoint its due place in Kant's Critical system and thereby recognize that conscience is an experienced reality that cuts across the opposition between our (theoretically conditioned) inclinations and our (practically conditioned) maxims, and once we recognize how insistent Kant is, throughout his Critical writings, on preserving a role for the transcendent despite human ignorance, the label 'mystical' comes to seem more plausible. Many read Kant as if his Critical principles prove the transcendent to be illusory. I believe all five of my interlocutors would agree this was never Kant's intention. The label 'Critical mysticism' merely acknowledges that Kant, having proven that theoretical reason cannot justifiably reject the transcendent, shows how practical reason positively justifies a rational faith that opens us up to the judicial possibility of experiencing it.

Pasternack (pp. I33-4) appeals to the second Critique's gallows example to support his claim that for Kant moral awareness is not mystical. But in that passage $(5: 30)$ Kant depicts the moral law as a transcendent source 
of our ability to resist inclination. That Kant does not appeal to 'divine communication' in this one passage does not negate the fact that he elsewhere calls the categorical imperative a 'voice' in the very context where he also describes God as 'a moral being' (e.g. OP, 22: I I 7; see also $\mathrm{CF}, 7: 63$, quoted at $K M$, p. 64). In assessing my interpretation of Kantian conscience as a mystical 'voice of God', Pasternack reads my references to such passages as if I were claiming that Kant intended them to be taken 'literally' (p. I33, Pasternack's emphasis); but KM never makes or even hints at such a requirement. Quite to the contrary, to emphasize its metaphorical status, I sometimes use scare quotes when referring to Kant's position (e.g. "'God's voice"' at p. I37). Pasternack's assessment, that it is 'incorrect' to regard conscience as God's voice (ibid.), rejects Kant's metaphor, not mine. Accordingly, Maharaj's allegation (p. I I I, n. 6) that I mislead the reader into thinking that Kant himself wrote the passage that I quote from Adickes, where he summarizes Kant's position about 'the categorical imperative' being 'the voice of God' (KM, p. I03), is unfounded; had Maharaj checked the note added to that very quote (p. I I I), he would have seen that I explicitly cite Adickes' book as the quote's source, not Kant's Opus Postumum. Moreover, this is a moot point because Adickes' words are a very accurate summary of what Kant himself says in several texts; see, for example, p. I03, where I quote Kant's own use of the exact phrase 'voice of God' in Conjectural Beginning of Human History (8: II I; see also KM, pp. 59, 65, I03). The point of KM's argument is not that Kant explicitly endorses Critical mysticism but that Critical philosophy paves the way for it - e.g. by explaining how such moral symbolism can replace the usual literal interpretations of such experiences. Far from 'blur[ring] this distinction' between the literal and the symbolic, the success of $K M$ 's argument hinges on my repeated references to the important role symbolism plays for Kant.

Despite his insightful recognition of the importance of a holistic vision to my conception of Critical mysticism, Nelson shares Pasternack's and Maharaj's misgivings about my use of the term 'mysticism'. His worry is that 'Kant's and our own contemporary negative associations with this controversial category' (p. I22) make it unwise to broaden the term's meaning. Nelson recommends 'Critical ethos' as a better way to express Kant's holistic vision of humanity's being-in-the-world, with its deep reverence for the beauty and sublimity of nature as well as for freedom and the moral law. My response echoes the sixteenth-century German maxim that we must take care lest we 'throw the baby out with the bathwater': something of real value is lost if we reduce mystical 
experience to a mere ethos. Critical mysticism, as I understand it, encompasses not just the experience of good character (i.e. ethics) that our being-in-the-world ought to exhibit, but also the experience of pathos (i.e. feeling) that is aroused by our awareness of the beauty, sublimity and organized purposes we find in nature, and the experience of logos (i.e. fact-based understanding) that a right-thinking person nurtures. To limit the experience of Critique in a way that fails to encompass the whole range of human faculties that Kant affirmed, simply because one is worried about offending the biases of readers - even if they be the majority of readers - who dislike the word, would be to sacrifice what is most admirable about enlightened philosophy, the courage to forge a new path.

Finally, let me address Firestone's main challenge: does $K M$ have 'more explanatory power ... than other metaphysically affirmative readings' (p. IOO)? Admittedly, KM spills very little ink contrasting my hermeneutic approach with others - most notably, perhaps, that of Firestone's own 2008 book co-authored with Nathan Jacobs, In Defense of Kant's Religion, which takes explanatory power as its primary rhetorical methodology. My decision not to argue by comparing the explanatory power of different interpretations per se was part and parcel of the choice to adopt the hermeneutic of insight described in section 3 . I recognize that for many philosophers one has not proved one's case until one has conducted the 'explanatory power' test. Limitations of space allow me to fill this gap here only by sketching what I would cover, were I to address Firestone's challenge fully.

Portraying the experience of Critique as a non-delirious way of being mystical has the following advantages over non-mystical interpretations. First, it enables readers to expect and accept the tolerance of paradox and mystery found throughout Kant's texts as accurate and intentional portrayals of the way things are, rather than requiring interpreters to explain them away or lament them as weaknesses or inconsistencies. Second, it explains why the first topics Kant turned his attention to after finishing the third Critique were an essay portraying 'authentic theodicy' as experiential ('On the Miscarriage of all Philosophical Trials in Theodicy'), followed by his Religion, which depicts the true nature and function of religion as providing a (moral) way to experience the ultimate without falling into delirium. Third, KM's hermeneutic transforms the stories of Kant's life and habits from being evidence of a quirky (perhaps even psychologically disturbed) personality to being testimony to the depth of his existential awareness of what it means to be human. And fourth, interpreting Critique 
as essentially mystical enables us to explain why Kant's philosophy was orientated towards an affirmation of religion (considered rightly!) even though Kant himself shunned organized religion for most of his adult life. By contrast, the interesting theses advanced by In Defense of Kant's Religion - e.g. the Aristotelian roots of Kant's approach to evil in the First Piece of Religion and the Platonic roots of his theory of the archetype in the Second Piece - may help explain the wording of specific passages in Religion, but such theses offer little help in explaining the aforementioned broader concerns. KM does not set out to explain specific passages of Kant's Religion as thoroughly as many other books do because it is not primarily an interpretation of religion. $K M$ is primarily an interpretation of Critique.

\section{Notes}

I Usually translated 'fanaticism' or 'enthusiasm'. For my detailed defence of the translation 'delirium', see Palmquist 2016: 520-I.

2 Early versions of four symposium essays and this response were presented at an Author Meets Critics session held at the 2017 Pacific Division Meeting of the American Philosophical Association. Thanks to Helmut Wautischer for organizing the session under the auspices of the Karl Jaspers Society of North America, and for his helpful feedback on the essays. Thanks also to the various participants who posed questions during the Q\&A, especially Lawrence Pasternack, whose questions foreshadowed his additional essay, published here. KM was initially to be published by Noesis Press in 2017 under the title Baring All in Reason's Light. Unfortunately, the publisher faced an unexpected crisis in early 2017; after a long delay, Diego Bubbio's entire 'New Studies in Idealism' series was transferred to Lexington Books.

3 Responding to several examples that I take as evidence of Kant's mystical tendencies, Maharaj declares that these do not qualify as 'mystical experiences', adding (p. Io8) that "there is no reason to believe that the very act of disciplined breathing is "likely" to result in mystical experiences'. Yet virtually every mystical tradition, including those found in major world religions and non-religious forms such as transcendental meditation and 'mindfulness', teaches its adepts to use disciplined breathing, typically at the beginning of their mystical pilgrimage. Likewise, most mystical traditions emphasize the importance of silence and solitude, both of which Kant practised with self-conscious, intentional discipline. If Maharaj does not count any of my examples (see especially $K M$, p. 70) as evidence of Kant's mystic-like tendencies, perhaps he has set the bar too high.

4 As I argue in section 4, some of Firestone's and Maharaj's misgivings stem directly from their neglect of this key point of KM's argument, which (among the five critics) only Nelson explicitly acknowledges.

5 Nelson observes that 'the sustained commentary on Swedenborg comes late, almost as an addition, such that it might be interpreted as a secondary concern or an example that illustrates the prior concern with the possibility of a genuine metaphysics' (p. I22). Kant's personal attacks on Swedenborg do, indeed, appear in Part Two of Dreams; but in Part One Kant thoroughly interacts with Swedenborg's theory of spirit-seeing. Moreover, Kant there says the metaphysical theories that 'elucidate' Swedenborg's mystical experiences are Kant's own, not Leibniz's. Similarly, Nelson's pertinent quote (p. I24) from Kant's Inaugural Dissertation, where Kant employs the same metaphor later made famous at A235-6/B294-5 - truth, the 'island' of experience (a metaphor 
Firestone also cites), contrasts with illusion, the 'ocean' of speculative metaphysics explicitly confirms that Kant saw Malebranche (like all speculative metaphysicians) as having 'mystic' tendencies. Indeed, even in 1770 Kant acknowledges that Malebranche's mystical position is 'pretty nearly what has here been expounded' (2: 4IO). KM merely fleshes out what such hints might imply, showing what Kant's historical context prevented him from explicating - that mystical experience can be authentically Critical.

6 McQuillan (p. I I6) defines Kant's 'critical method' - a term Kant himself never uses in his published writings - by quoting from Axii. But Axii is not about method; rather, Kant there outlines the first edition's equivalent to the new 'hypothesis' that the second edition's more precise account associates with Copernicus (e.g. Bxxii, n.). McQuillan's prior quote from Dreams (2:349) aptly illustrates what I mean by 'Critical method'.

7 If McQuillan's assertion, that 'More historical-critical work would have to be done to substantiate the claims Palmquist makes in KM' (p. I I6), refers to my claim that the Critical method as I define it appears throughout Kant's writings, then I agree. I did some of that work in Palmquist I993, but I have never systematically traced this claim throughout Kant's writings. McQuillan is correct if he means I do not 'substantiate' this claim in KM itself; but I provide ample evidence supporting the claim about Kant's discovery of the Copernican hypothesis.

8 On McQuillan's fourth repetition of this objection, he claims my position is that Kant's method 'was "well-formed" during the mid-I76os' (p. I 16, my emphasis). Yet I never portray Kant as completing any such formation during that decade. Again, I detect the Critical method operating well before the 1760 s, while the Copernican hypothesis only began to form (as a mere seed) during that decade.

9 Dreams, 2: 369, my translation; cf. KM, p. 26.

Io McQuillan summarizes the four chapters in Part One of Dreams (p. I I6) without explicitly noting the threefold, perspectival development that $K M$ claims those chapters exhibit, but also without challenging my demonstration that these chapters exhibit Kant's standard Critical methodology. In order to refute my claim, McQuillan would need to show that chapter 3 in Dreams does not offer a sceptical negation of the Kantian/Swedenborgian metaphysical explanation of spirit-seeing that Kant dogmatically defends in chapter 2 , and that chapter 4 does not synthetically resolve the foregoing opposition.

I I Thus Firestone is right to portray $K M$ as arguing that Kant 'wants to promote something in [Swedenborg's work]', but wrong to think this means that Kant did not want 'to dismantle and destroy it' (p. Ior). In order to pave the way for Critical metaphysics/ mysticism, Kant had to reject delirious mysticism just as much as he rejected speculative metaphysics.

I2 Palmquist (I993) anticipates Pasternack's concern over the apparent dispensability of perspectives-language by explaining that each Kantian 'perspective' establishes the necessarily correct 'interpretative stance' required to answer a specific type of philosophical question. That is, the principles governing Kantian perspectives are not optional but they function only when we are adopting the corresponding perspective.

I3 Nelson echoes this sentiment: holistic experience (cf. Critical mysticism) 'is disclosed not in the fantastic but in ordinary encounters with others, things, and environments' (p. I26).

I4 Especially Palmquist (I987), revised and reprinted as chapter 4 in Palmquist (I993).

I5 Surprisingly, Pasternack (p. I30) claims that 'immediate experience' in $K M$ 'means something other than' Kant's original, purely epistemological meaning. While my application of this term surely goes beyond Kant's, I would dispute the charge that I have thereby 
changed the meaning. The issue here is whether Kant allows the forms of intuition and the forms of conception to operate separately. Pasternack seems to assume he does not; I claim that he does. Normally for Kant 'experience' is 'mediate' in the sense that intuition and conception work together, but Kant explicitly allows for situations where they are delinked: 'intuitions without concepts are blind' ( $\left.\mathrm{A}_{5} \mathrm{I}_{\mathrm{B}} \mathrm{B}_{75}\right)$ because they are immediate.

I6 See Palmquist (I993: 24, n.). A similar point applies to many of my contributions to Kant interpretation. For example, when I argue that some of Kant's most significant theories establish analytic aposteriority (e.g. Palmquist I993: I34-9; cf. Palmquist 20 I 2), I never claim that Kant himself thought of them this way. Rather, while I agree with the vast majority of what Kant argues, I set out to correct him when I think he goes astray. If Firestone believes I misunderstood the several passages I quote in $K M$ when illustrating Kant's own views on immediate experience, I welcome him to regard this as part of my reconstruction of Kant. To me, it makes little difference which claims one labels as exegesis and which as eisegesis, provided readers agree that the resulting claims are worthy of adherence. Thus, if 'there is no way to work out exegetically where Kant ends and eisegetically where Palmquist begins' (p. I02), I wear this as a badge of honour; for the same could be said of Kant, and of any great philosophical work in relation to its roots.

I7 I illustrate how this might be done in Palmquist (20I3) and in a series of other articles relating Kant and the Yijing.

I8 Maharaj apparently thinks the mystics in Kant's example had an experience of conscience without interpreting it, whereas ' $[\mathrm{t}]$ he vast majority of us ... can only interpret our non-mystical experience of conscience as an experience of God's voice' (p. I09). Again, this hinges on how one defines 'mystical': if Maharaj refuses to grant my definition, whereby Critique can be a mystical experience and mysticism can be Critical, then no possible argument would convince him. By contrast, McQuillan concludes by supporting this overall claim in KM: given my revised definition of what 'mystic' means, he says, 'I suspect Palmquist is right' (p. II6).

19 This is why, as Pasternack rightly observes (p. I32), Kant 'recommends agnosticism towards claims' that specify too precisely the nature of one's religious/mystical experiences.

20 The same goes for Nelson's claim that Leibniz's 'idea of a universal society of spirits ... is primarily understood as a moral republic of ethical persons ... rather than a mystical form of the communion of spirits' (p. I25, my emphasis). Obviously, Kant rejects the latter in Swedenborg's delirious sense; but this does not mean he would automatically reject KM's suggestion that his Critical philosophy paves the way for an enlightened mysticism, just as it did for metaphysics.

2I Maharaj thinks it strange that I interpret a quote from the Collins Lectures, about 'know[ing] God, not by intuition, but through faith' (27:337-8; see KM, p. 67), as supporting Critical mysticism when it explicitly affirms the role of (rational) faith. But the context of this passage depicts practical reason as a mode of experience that offers the Critical antidote to supposed intellectual intuition of God.

22 Many mystics - both East and West - readily embrace such paradoxes, as Nelson inadvertently admits (p. I 20). For my detailed defence (and numerous examples) of the claim that paradox and mystery go hand in hand, see Palmquist (200ob), part four.

23 Like Nelson, I argue elsewhere that Mou's strange claims about intellectual intuition indicate that he assumed a different definition of that term than Kant's. In Kant's terminology, the ideas of reason, with their holistic vision of the totality of knowledge conveyed to reason by the understanding, are the proper human substitute for intellectual intuition. Kant's much-neglected distinction between two types of Gegenstand, sensible and supersensible (or phenomenal and noumenal), is an important key to understanding the restrictions he puts on theoretical reason for the Critical mystic. Claims to possess 
intellectual intuition wrongly interpret the experience of certain sensible Gegenstände as if an intellectual Objekt were given (see Palmquist 2020); our experience of supersensible Gegenstände really is (merely) intellectual, so such experience (namely, reflection on the ideas of reason) can provide a holistic vision, yet without conveying any theoretical knowledge.

\section{References}

Hanna, Robert (20II) 'Kant's Non-Conceptualism, Rogue Objects, and the Gap in the B Deduction'. International Journal of Philosophical Studies, I9, 399-4 I 5.

Maharaj, Ayon (2017) 'Kant on the Epistemology of Indirect Mystical Experience'. Sophia, 56,3 II -36.

Palmquist, Stephen R. (1987) 'Knowledge and Experience: An Examination of the Four Reflective "Perspectives” in Kant's Critical Philosophy'. Kant-Studien, 78, I70-200.

(I988) 'Kant's Critique of Mysticism: (I) The Critical Dreams'. Philosophy and Theology, 3, 355-83.

(r989) 'Kant's Critique of Mysticism: (2) The Critical Mysticism'. Philosophy and Theology, 4, 67-94.

(I993) Kant's System of Perspectives: An Architectonic Interpretation of the Critical Philosophy. Lanham, MD: University Press of America.

— (1996) 'How “Chinese” was Kant?'. The Philosopher, 84, 3-9.

(2000a) Kant's Critical Religion: Volume Two of Kant's System of Perspectives.

Aldershot: Ashgate.

(200ob) The Tree of Philosophy: A Course of Introductory Lectures for Beginning

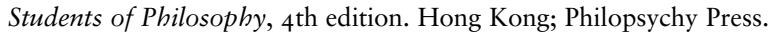

- (20I2) 'Analytic Aposteriority and its Relevance to Twentieth Century Philosophy'. Studia Humana, I, 3-I 6.

_ (2013) 'A Daoist Model for a Kantian Church'. Comparative Philosophy, 4, 67-89.

- (2016) Comprehensive Commentary on Kant's Religion within the Bounds of Bare Reason. Chichester: Wiley.

(2019) Kant and Mysticism: Critique as the Experience of Baring All in Reason's Light. New York: Lexington Books.

(2020) 'An Analysis of Kant's Use of the Terms Objekt and Gegenstand'. In Gisela Schlüter and Hansmichael Hohenegger (eds), Kants Schriften in Übersetzungen, special issue I 5 of Archiv für Begriffsgeschichte (Berlin: de Gruyter), 57I-9I. 